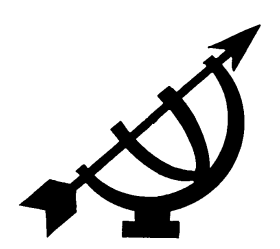

\title{
Die hart van die mens herontdek: op die spoor van 'n Skrifgetroue mensbeskouing in die filosofie van D.H. Th. Vollenhoven
}

\author{
B.J. van der Walt \\ Skool vir Filosofie \\ Potchefstroomkampus \\ Noordwes-Universiteit \\ POTCHEFSTROOM \\ E-pos: hannah@intekom.co.za
}

\begin{abstract}
The heart of humankind rediscovered: on the track of a Scriptural view of being human in the philosophy of D.H. Th. Vollenhoven
\end{abstract}

This article provides a summary of the anthroplogy of the reformational philosopher, D.H. Th. Vollenhoven (1892-1978). Such a synopsis is needed because Vollenhoven himself never worked out his views on being human in detail. The "fragments" from his different writings as well as some books about his philosophy are therefore collected in order to clarify the basic contours as well as uniqueness of his viewpoint. This is done in the light of the fact that many Christians even today are still influenced by all kinds of unbiblical anthropological ideas. The investigation develops from an introduction that indicates the need and topical nature of the research. This is followed by an explanation of Vollenhoven's historical and systematic approach as well as the development of his own anthropological views. It is then indicated how he (with his problem-historical method) analysed the great variety of anthropologies throughout history. The next section contains a systematic exposition of his own views on being human, which is followed by an indication of its contemporary relevance. The concluding section consists of a review and final evaluation. 


\section{Opsomming}

Die hart van die mens herontdek: op die spoor van 'n Skrifgetroue mensbeskouing in die filosofie van D.H. Th. Vollenhoven

Hierdie artikel bied 'n samevatting van die mensbeskouing van die reformatoriese filosoof, D.H. Th. Vollenhoven (1892-1978). So 'n sinopsis is noodsaaklik, aangesien Vollenhoven self nooit sy antropologie volledig uitgewerk het nie. "Fragmente" uit sy verskillende geskrifte en ook enkele werke oor sy filosofie word dus hierin byeengebring, sodat die hoofkontoere asook die uniekheid van sy visie duidelik sal blyk. Dit word gedoen in die lig van die feit dat baie Christene vandag nog steeds onbybelse gedagtes oor die mens huldig. Die ondersoek ontwikkel vanaf 'n inleiding wat eerstens die noodsaak en aktualiteit van die navorsing verduidelik. Dit word opgevolg met ' $n$ verduideliking van Vollenhoven se historiese en sistematiese benadering tot die filosofie, asook die ontwikkeling van sy eie antropologiese idees. Daarna word aangetoon hoe hy (met behulp van sy probleem-historiese metode) die groot aantal antropologieë deur die geskiedenis geanaliseer het. Die volgende afdeling bevat 'n sistematiese uiteensetting van sy eie visie op menswees wat gevolg word met ' $n$ aanduiding van die huidige relevansie daarvan. Die afs/uiting bestaan uit 'n terugblik en finale evaluering.

\section{Inleiding: 'n belangrike leemte}

Ter inleiding word kortliks gekyk na die sleutelrol van 'n mensvisie, die leemte dat die vaders van die reformatoriese filosofie nie hulle mensbeskouings volledig uitgewerk het nie, asook die moontlike oorsake waarom Vollenhoven hierdie aspek van sy filosofie nie verder uitgebou het nie.

\subsection{Die grondliggende rol van 'n mensbeskouing}

Naas ' $n$ mens se visie op die hele werklikheid (in die filosofie ontologie genoem), wat ook jou visie op die mens bepaal, is 'n mens se visie op die mens self (antropologie genoem) grondliggend vir alle ander fasette van die lewe. Dit bepaal byvoorbeeld hoe die menslike samelewing beskou en gestruktureer word, want hoe 'n mens die mens sien, is deurslaggewend vir hoe jy hom/haar/hulle behandel. Indien die mens niks meer as 'n fisies-chemiese wese sou wees nie (vgl. afdeling 5), mag hy soos 'n objek behandel word. Word die mens slegs as 'n biologiese wese beskou, hoef hy nie beter as 'n dier behandel te word nie. Wanneer hy homself primêr as van ekonomiese aard beskou - nog 'n voorbeeld van die reduksie 
van ware menswees - word produksie en verbruik heelwaarskynlik sy eie lewensdoel en ook dié van die breër samelewing (vgl. die hedendaagse kapitalisme). Om oor 'n mens se mensbeskouing te besin, is dus noodsaaklik en relevant.

\subsection{Die huidige leemte}

Hierdie artikel wil in 'n leemte binne die reformatoriese filosofie voorsien, naamlik dat dit by die grondleggers daarvan nie 'n volledig uitgewerkte mensbeskouing bied nie. Twee van die vaders van hierdie Christelike wysbegeerte, H. Dooyeweerd (1894-1977) en D.H. Th. Vollenhoven (1892-1978) het hoogstens die hoofkontoere van 'n Skrifgetroue mensvisie nagelaat.

Dooyeweerd gee in 'n aantal stellings (vgl. Dooyeweerd, 1942) slegs die hooftrekke van sy mensvisie en belowe later (vgl. Dooyeweerd, 1949:13) dat hy 'n tweede en derde band sal publiseer waarvan die laaste sy volledige antropologie sal bevat. (Hierdie belofte word ook in Dooyeweerd, 1957:781 herhaal.) Dit het egter nooit gerealiseer nie. Hy gee in twee kort stukke op 'n later datum (vgl. Dooyeweerd, 1960 en 1961) wel die hooftrekke van sy mensbeskouing weer.

Oor sy mensvisie het ook Vollenhoven min nagelaat. Dit is meestal beperk tot flitse en fragmente in verskillende geskrifte. Vandaar die subtitel van hierdie artikel "op die spoor van ..." Dit is 'n poging om dit wat oor verskillende bronne verspreid voorkom, te probeer saamvat en so sy belangrike bydrae tot die antropologie, veral vir persone wat onbekend is met sy denke, meer toeganklik te maak.

Daar word verder net op Vollenhoven toegespits, omdat Dooyeweerd as gevolg van die vroeëre vertaling van sy werke in Engels vandag meer bekend en toeganklik is. Daar is ook reeds heelwat oor sy mensvisie geskryf (vgl. byvoorbeeld De Graaff, 1977 en 1979; Fernhout, 1975; Ouweneel, 1984 en 1986).

\section{3 'n Moontlike oorsaak vir die leemte by Vollenhoven}

Op die vraag waarom Vollenhoven nie sy antropologie verder uitgewerk het nie, sou verskillende antwoorde gegee kon word soos byvoorbeeld dat die tyd daarvoor ontbreek het, dat sy bestudering van die geskiedenis van die filosofie by hom prioriteit geniet het en nog meer. Heelwaarskynlik bestaan daar verskillende redes voor. My vermoede is dat die jarelange kerklike stryd waarin Vollenhoven ook betrokke geraak het hom moontlik ook daarvan weerhou het om verder aan sy mensbeskouing te werk. Vollenhoven sê self dat ver- 
skille oor die wysgerige antropologie nie die kerk moet verdeel nie (vgl. byvoorbeeld sy brief aan Schilder in De Vries, 1992:43). Hierdie onsmaaklike stryd kan verder volledig nagegaan word in Stellingwerff (1987 en veral 1992) asook De Vries (1992).

\subsubsection{Antropologie dié twispunt}

Aangesien hierdie stryd ook die konteks waarteen Vollenhoven sy eie mensvisie moes uitwerk duidelik maak, word dit kortliks weergegee. Hoewel die twis ook oor ander sake (soos die menslike natuur van Christus) gegaan het, het die stryd rondom die mensvisie 'n belangrike deel daarvan uitgemaak.

Die destydse gereformeerde denkers, veral die teoloë, het meestal 'n digotomistiese antropologie gehuldig. Daarvolgens sou die mens uit twee afsonderlike substansies bestaan, naamlik liggaam en siel wat op die een of ander wyse met mekaar verbind is. Soms is ook in plaas van 'n digotomie, 'n trigotomie voorgestaan. Die mens bestaan dan uit liggaam, siel en gees. Die siel is nie alleen as die hoëre en belangrikste "deel" van die mens beskou nie, maar ook as die onsterflike komponent wat na die opstanding weer met die liggaam verenig sou word.

\subsubsection{J. Waterink}

Waterink (1890-1966), Vollenhoven se kollega aan die Vrije Universiteit van Amsterdam, was 'n verteenwoordiger van so 'n Christelike (trigotomistiese) mensbeskouing. Vollenhoven het egter ernstige besware gehad teen Waterink se boek, De oorspong en wezen der ziel van 1930 (vgl. Stellingwerff, 1987:187-201). Reeds in 1929 kritiseer Vollenhoven die gedagte dat die sielkunde die "siel" (i.p.v. net die psigiese aspek van die mens) sou bestudeer. Volgens hom is die idee van siel en liggaam as op sigself bestaande onderdele van die mens 'n onbybelse gedagte uit die pagane Griekse denke (vgl. Stellingwerff, 1992:94).

\subsubsection{Reformasie deur A. Janse}

Na sy promosie (1918) ontstaan 'n noue kontak tussen Vollenhoven en Janse (1890-1960). Stellingwerff (1992) wys telkens daarop. In tydskrifartikels maak Janse reeds in 1923 (vgl. Janse, 1940:3) beswaar teen bogenoemde digotomistiese en trigotomistiese mensvisies en weerlê dit in die lig van die Skrif (vgl. Janse, 1934; 1938 en 1940). 
Hierdie nuwe antropologie van Vollenhoven en Janse word egter deur baie in die destydse gereformeerde wêreld, in die pers en ander publikasies, as revolusionêr, in stryd met die kerklike belydenis, teologie en selfs die Skrif beskou.

\subsubsection{By die sinode aangekla}

Die beskuldigings teen Vollenhoven en sy medestanders lei daartoe dat die sinode van die Gereformeerde Kerke in 1936 'n kommissie benoem om die aanklagte in die lig van die Skrif en belydenis te toets. (Vgl. De Vries, 1992, voetnoot 39 vir die lede van die kommissie.)

Terwyl die kommissie egter met sy werksaamhede besig was, skryf een van die lede, V. Hepp (1879-1950), 'n hele reeks brosjures onder die titel, Dreigende deformatie, waarin hy sommige van sy mede-kommissielede (w.o. Schilder en Vollenhoven) van "deformasie" beskuldig. Dit word 'n lang uitgerekte sage. Vollenhoven en Dooyeweerd het hulle as gevolg van die ongegronde beskuldigings in die openbaar later verplig gevoel om 'n eie, afsonderlike rapport by die sinode van 1939 in te dien (vgl. De Vries, 1992:181, voetnoot 105). Die hele aangeleentheid, deur die Tweede Wêreldoorlog verder vertraag, is nooit bevredigend opgelos nie.

Hierdie kort oorsig laat nie alleen blyk teen watter agtergrond Vollenhoven se reformasie van die mensvisie moes plaasvind en hoe "heilig" mense se visie op die mens kan wees nie, maar dit was dalk ook een van die redes waarom Vollenhoven nie meer oor sy mensbeskouing gepubliseer het nie. Reformasie op hierdie gebied was destyds nie maklik nie!

\subsection{Blywende betekenis}

Stellingwerff (1992:255, 256; vgl. ook 2006:46 e.v.) maak egter aan die einde van sy boek oor Vollenhoven die opmerking dat, hoewel die omstandighede vandag verskillend is, sy program van reformasie aktueel bly. Hy noem Vollenhoven selfs "'n wysgeer van alle tye" (Stellingwerff, 1992:255).

Myns insiens, tereg. Luister maar na preke, veral by begrafnisdienste, lees die talle populêre artikels en boekies oor wat met die mens by die dood gebeur, bestudeer selfs wetenskaplik-teologiese publikasies oor die mens en jy besef gou hoe baie Christene nog steeds vasgevang is in 'n wesenlik onskriftuurlike mensbeskouing. 
Wat Stellingwerff (1992:256) aanbeveel, naamlik dat die jongere generasie Vollenhoven se Christelike filosofie moet herontdek, geld ook van sy mensbeskouing. Stellingwerff se wenk word hier opgevolg. Soos 'n spoorsnyer sal op Vollenhoven se voetspore geloop word. Geleidelik sal blyk dat sy mensvisie veral tot 'n herontdekking van die Bybelse begrip "hart" gelei het. 'n "Voorbode" daarvan vind 'n mens alreeds by Vollenhoven (1950:26), waar hy skryf dat die hart as setel van die religie deur geen Griekse of Hellenistiese denker raakgesien is nie. "De diepte van het menslijke leven was de paganisme reeds vroeg ontgaan."

Ter voorbereiding van die speurtog moet egter eers iets meer in die algemeen oor sy denke gesê word.

\section{Vollenhoven se filosofie in die algemeen}

Dit is nodig om iets te noem oor die noue samehang tussen Vollenhoven se historiografie van die filosofie en sy sistematiese filosofie, asook iets oor sy eie filosofiese ontwikkelingsgang. ${ }^{1}$

\subsection{Die samehang tussen sistematiek en geskiedenis by Vollenhoven}

Reeds in 1933 beklemtoon Vollenhoven dat 'n mens sonder 'n deeglike kennis van die geskiedenis van die filosofie nie 'n eie verantwoorde standpunt kan bereik nie. Omgekeerd kan 'n mens nie die geskiedenis van die wysbegeerte sonder 'n (voorlopige) eie visie benader nie. "Bij de behandeling van een wijsgerig vraagstuk is het niet mogelijk een welgefundeerd oordeel te vellen zoolang niet de systematiek en de geschiedenis haar woord hebben gesproken." (Vollenhoven, 1933:10.) Kok (1996) volg later dié raad deur 'n gepopulariseerde weergawe van sowel Vollenhoven se oorsig oor die Westerse wysbegeerte as Vollenhoven se eie sistematiek in een boek uit te gee.

\subsubsection{Die probleem-historiese metode}

Vir sy bestudering van die 2500-jarige geskiedenis van die Westerse denke ontwikkel Vollenhoven oor baie jare sy konsekwent probleem-

1 Verskeie publikasies van en oor Vollenhoven is deesdae ook op die internet beskikbaar. (Vgl. die eerste inskrywing onder Vollenhoven in die Geraadpleegde bronne aan die einde van die artikel.) Verder bestaan daar 'n VollenhovenArgief by die Vrije Universiteit in Amsterdam, Nederland, asook 'n Vollenhoven Stigting (die e-posadres van die sekretaris, dr. K.A. Bril, is: ka.bril@planet.nl). 
historiese metode en publiseer die eerste vrugte daarvan in 1950 (Vollenhoven, 1950). Die lywige boek dek nog net die geskiedenis van die Griekse wysbegeerte vóór Plato en dit was dus net die begin van 'n ideaal om die hele, aanvanklik onoorsigtelike, labirint van wysgerige konsepsies "in kaart te brengen" (Vollenhoven, 1950:6). Uit die uiteensetting van sy metode wat hy hier bied, blyk weer hoe nou sy historiografiese metode verbind is met sy eie ontologie. Die verdere verloop van die geskiedenis van die Westerse filosofie kon Vollenhoven net kortliks in sy Kort overzicht van de geschiedenis van de wijsbegeerte (1956) skets (kort gelede heruitgegee in Vollenhoven, 2005a:21 e.v.; ook 'n Engelse vertaling in Vollenhoven, 2005b). Vir oningewydes bied Bril (1986 en 2005 en Tol \& Bril, 1992) 'n goeie inleiding tot hierdie metode. lets meer sal oor die metode gesê word wanneer aangetoon word hoe Vollenhoven dit op die antropologie toepas.

\subsubsection{Vollenhoven se eie sistematiese filosofie}

Volgens Vollenhoven (2005d en 2005e) moet 'n Christelike denker op die volgende drie basiese vrae antwoorde verskaf: Wie is die Skepper? Wat is dit wat Hy geskep het? Waar lê die lyn tussen albei? In sy eie sistematiese filosofie onderskei hy dus, sonder om hulle te skei, God, die skepping (kosmos) en die wet as "grens" tussen die twee. Vollenhoven se onderskeid is nie bedoel as drie synswyses in ontologiese sin nie, want nóg God nóg sy wet kan in 'n synsleer opgeneem word - die ontologiese slaan slegs op die skepping (vgl. Vollenhoven, 2005c:301). Dit is belangrik om hier ter kennisname by te voeg dat Vollenhoven nie net 'n onderskeid tussen God, wet en skepping maak nie, maar ook die verhouding tussen hulle uitwerk.

Hierdie werklikheidsvisie stel Vollenhoven teenoor die dualisme wat 'n oorspronklike tweeheid ('n transendente en 'n nie-transendente) aanvaar en wat volgens hom tot deïsme lei, naamlik dat God onbetrokke is by die kosmos. Hy stel dit egter ook teenoor die monisme, wat net een werklikheid of bestaan aanvaar, waaruit (sekondêr) die veelheid voortvloei en dus tot panteïsme (alles is goddelik) lei.

Hierdie basiese uitgangspunt van Vollenhoven het belangrike implikasies vir sy mensbeskouing. Daarmee word byvoorbeeld byvoorbaat uitgesluit dat daar in die mens sprake kan wees van iets semigoddeliks (bv. sy siel). 


\subsection{Vollenhoven se eie ontwikkeling}

Soos meeste filosowe vertoon Vollenhoven se antropologiese denke ook ontwikkeling. Dit blyk uit die volgende.

\subsubsection{Prioriteitsleer}

Gedurende die twintigerjare (ná sy promosie in 1918) huldig hy nog 'n digotomie (tweedeling) in sy mensbeskouing. Die menslike wese is daarvolgens 'n spesiale sintese tussen 'n fisiese substansie (die liggaam) en 'n psigiese substansie (die siel) (vgl. Kok, 1992:37). Die verhouding tussen die siel (die hoëre) en die liggaam (die laere) is dat eersgenoemde wel op die een of ander manier op die laere 'n invloed uitoefen, maar self geen invloed van die laere ondervind nie. Vollenhoven self tipeer so 'n beskouing later as 'n "prioriteitsleer" (vgl. Vollenhoven, 2000:373).

\subsubsection{Wisselwerkingsteorie}

Later is Vollenhoven egter van mening dat 'n bepaalde vorm van die wisselwerkingsteorie beter aan die werklike stand van sake ten opsigte van die mens reg laat geskied. Dit was dieselfde antropologie wat Vollenhoven se leermeester, J. Woltjer, ook in sy latere lewe voorgestaan het (vgl. Van der Laan, 2000:243, 244). Hier word dít wat Vollenhoven later as die pneumatistiese wisselwerkingsteorie sou aandui, nog die energetiese wisselwerkingsteorie genoem (vgl. Bril, 1982:13 en Vollenhoven, 2005c:441). Dit beteken egter nie dat die pneumatistiese wisselwerkingsteorie (vervolgens as pwwt afgekort) Vollenhoven se eie visie op die mens weergee nie. Dit is immers die gevolg van 'n monistiese ontologie, wat nie as 'n Skriftuurlike standpunt beskou kan word nie (vgl. verder 3.5 en 3.6).

\subsection{Invloed van Janse}

Vollenhoven het vir die ontstaan van sy eie meer Bybelgetroue mensvisie heelwaarskynlik baie aan Janse (vgl. 1.3.3 hierbo) se baanbrekerswerk op hierdie gebied te danke gehad. Bril vermeld (in Vollenhoven, 2005c:202, 440) dat Vollenhoven hom selfs in die laaste jare van sy lewe weer met Janse se werk, De mensch als 'levende ziel' (1934), besig gehou het.

Daarin en in sy ander publikasies oor die mens weerlê Janse in die lig van die Skrif die gedagte dat die mens 'n digotomistiese kombinasie van stof en gees is. Die mens het nie 'n siel nie, maar die (hele) mens is siel, 'n lewende wese. Die Bybel ken ook nie 'n onsterflike siel nie. Dit is nie die onsterflikheid van die siel nie, maar die 
almagtige God wat die mens deur die dood dra. Hiermee bevraagteken Janse dus nie 'n lewe na die dood nie. Hy lê klem op die eenheid van die mens in hierdie lewe, op die feit dat die mens by die dood gebreek word en op sy opstanding by die wederkoms van Christus. (Vir meer besonderhede oor Janse en sy mensvisie, vgl. Van der Walt, 2008a:202-206.)

\subsection{Verdere opset}

Hiermee is voldoende agtergrond gebied om na die volgende twee afdelings van hierdie ondersoek oor te gaan. Eerstens hoe Vollenhoven met behulp van sy probleem-historiese metode die groot verskeidenheid antropologieë deur die geskiedenis gekarteer het en watter een van hulle die naaste aan die waarheid gekom het. Tweedens hoe die kontoere van sy eie antropologie in die lig van God se openbaring in natuur en Skriftuur daar uitsien.

\section{Vollenhoven se historiografiese beoordeling van die Westerse mensvisies deur die eeue}

Aangesien Vollenhoven se probleem-historiesemetode deur homself (vgl. Vollenhoven, 1950:11-21 en ook 2005a) asook andere (vgl. Bril, 2005; Van der Walt, 2006 en 2008b) verduidelik is, hoef dit nie weer hier in detail te gebeur nie. Slegs die noodsaaklikste word verduidelik om sy visie op die mens te kan verstaan.

\subsection{Tydstrominge en tipes}

Vollenhoven deel die hele geskiedenis van die Westerse denke in drie hooftydperke in, naamlik die voor-sintese denke (van die Grieke en Romeine), die (Christelike) sintesedenke (van die Kerkvaders en die Middeleeue) en die na-sintese of anti-sintetiese denke (vanaf die Reformasie en die Renaissance).

Binne hierdie drie tydperke kom daar 'n groot verskeidenheid filosofiese strominge voor. 'n Stroming dui die bepaalde gees of rigting van 'n tydperk aan, want dit bied 'n antwoord op die vraag watter wet(te) of norm(e) die mens se lewe moet lei. Dit bind dus 'n groep denkers binne ' $n$ bepaalde periode saam. Omdat so 'n visie op die normatiewe verander, verander strominge voortdurend en is daar ' $n$ dinamiese element in die geskiedenis van die filosofie. (Vir die verskillende strominge, vgl. Vollenhoven, 2005a:157-160.)

Alle denkers binne 'n bepaalde stroming huldig egter nie presies dieselfde standpunt nie. Elke denker moet, behalwe 'n antwoord op die 
vraag "Wat moet ek doen?" of "Hoe moet ek lewe?", ook 'n antwoord gee op "Hoe lyk die werklikheid?", met ander woorde hoe lyk die grondstruktuur van dinge (stof, plant, dier en mens). Die antwoorde hierop lei tot verskillende tipes filosofieë - die konstante element dwarsdeur die geskiedenis. (Vgl. Vollenhoven, 2005a:161-163 vir die groot verskeidenheid tipes.)

Elke denker se filosofie word dus eers volledig beskrywe deur die stroming waarbinne hy/sy staan en die tipe filosofie (ontologie) wat hy/sy voorstaan. Eenvoudigheidshalwe sal verderaan hoofsaaklik op die tipes filosofieë en antropologieë gekonsentreer word en nie op die filosofiese strominge waarbinne hulle voorkom nie. Dit beteken nie dat filosofiese strominge nie vir die antropologie belangrik is nie. Antropologieë uit die voor-sintese, sintese- en anti-sintesedenke toon byvoorbeeld duidelike verskille. Ontologiese instellings en tydstrominge bepaal sáám die betrokke visie op die mens. (Vgl. 4.1 hieronder.)

\subsection{Verskillende antwoorde op die oorsprongsvraag}

'n Eerste belangrike vraag wat 'n denker moet beantwoord, is waar werklikheid vandaan kom. Sommige denkers gebruik mites (geloofsfantasieë) om dié vraag te beantwoord - selfs oor die ontstaan van die gode. Vollenhoven noem hulle dus mitologiserende denkers. Hierteenoor dink 'n ander groep suiwer kosmologies - hulle spekuleer nie oor die oorsprong van die dinge nie, maar beperk hulle tot die bestaande. 'n Derde groep dink kosmogono-kosmologies - hulle vermy dus nie die vraag oor die genese (ontwikkeling) van die kosmos nie.

Hoewel Vollenhoven laasgenoemde standpunt as die beste van die drie beskou (vgl. Bril in Vollenhoven, 2000:399), verskil hy as Christelike denker ook daarvan, want die oorsprongsvraag kan nie wetenskaplik-filosofies beantwoord word nie. Dit kan alleen in die geloof aanvaar word dat die God van die Bybel die Oorsprong (Skepper) van alles is - ook van die mens. Wie dit nie in die geloof aanvaar nie, verval noodwendig in blote spekulasie. Hoe die werklikheid begin het, asook hoe die lewe ná die dood lyk, kan nie wetenskaplik vasgestel word nie. Vir kennis daaroor is die mens heeltemal van God se openbaring afhanklik. 


\subsection{Monisme en dualisme}

'n Volgende vraag wat filosofies beantwoord moet word, is hoe die werklikheid saamgestel of gestruktureer is - dus hoe die eenheid en verskeidenheid daarin verklaar kan word.

Monistiese denkers was van mening dat daar oorspronklik net een bestaande of synde was waaruit die verskeidenheid deur vertikale divergensie voortkom. (Skematies voorgestel: 'n punt waaruit 45 grade na boontoe en $\mathbf{4 5}$ grade na onder twee pyle voortkom, wat die hoëre en laere afsplitsings uit die oer-eenheid voorstel.)

Hierteenoor huldig dualistiese filosowe die standpunt dat daar oorspronklik 'n tweeheid ('n transendente en nie-transendente) bestaan het. Die eenheid word verklaar deur die een of ander vorm van korrelasie tussen albei. (Skematies voorgestel: 'n reguit lyn met bokant die lyn die transendente en daaronder die nie-transendente.)

Indien hy moes kies, voel Vollenhoven hom nader aan die monisme. Sy eie visie (vgl. 2.1.2 hierbo) is egter nie monisties nie. In plaas van monisme en dualisme, onderskei hy tussen die volgende drie werklikhede: God (die Skepper), wat sy wette vir die skepping stel.

\section{4 'n Groot verskeidenheid mensvisies}

Sowel die monistiese as die dualistiese ontologie gee aanleiding tot 'n groot verskeidenheid mensbeskouings waarop nie hier verder ingegaan kan word nie (vgl. Vollenhoven, 2000 en 2005a).

Omdat dualiste daaroor verskil waar die grens tussen die transendente (godheid) en die nie-transendente presies getrek moet word, het dit ook antropologiese implikasies. Die mens kan as 'n suiwer nie-transendente wese beskou word, of as 'n wese wat iets transendents (bv. 'n siel) besit.

Monistiese denkers kan die aard van die hoëre en die laere afsplitsings (bv. siel en liggaam) uit die oorspronklike eenheid verskillend tipeer. Verder kan hulle ook die verhouding tussen die twee verskillend aandui. Voorbeelde hiervan is die parallelisme (wat leer dat die twee min of meer onafhanklik van mekaar bestaan), die prioriteitsleer (wat beweer dat slegs die hoëre 'n invloed op die laere het en nie omgekeerd nie) en die wisselwerkingsteorie (wat wedersydse beïnvloeding tussen die hoëre en laere komponente aanvaar). Vollenhoven (in Tol \& Bril, 1992:344) verduidelik die drie visies met duidelike diagramme. 
By die wisselwerkingsteorie (wwt) is daar ook verskillende opsies. Vollenhoven (2000:414) onderskei hier sewe tipes, waaronder die antropologiese, soölogiese, hedonistiese, fitologiese en pneumatistiese wwt. Van al hierdie tipes word slegs op laasgenoemde gelet. Daarvolgens is die sentrale deel van die mens die pneuma (asem, gees of lewensgees), wat die ander gedeelte van die mens (die liggaam) beïnvloed, terwyl die omgekeerde ook gebeur.

\subsection{Die naaste aan die ware stand van sake}

Daar word op die pwwt gekonsentreer, omdat dit volgens Vollenhoven die mees aanvaarbare is van die groot verskeidenheid mensvisies wat deur die eeue voorgestel is (vgl. 2.2.2 hierbo). Bril (in Vollenhoven 2005c:440) sê "Vollenhoven meende dat, vergeleken met ander typen, deze lijn het meeste recht doet aan de gegevens van de geschapen werkelijkheid, zonder daarvan een aanhanger te zijn." (Kursivering - BJvdW.)

Direk daarna volg 'n aanduiding van Vollenhoven se eie visie: "Pas het zien van de innerlijke mens geeft zicht op een Schriftuurlijke antropologie." (Vgl. ook Bril, 1982:111 en Bril in Vollenhoven, 2000: 231, 271 en 399.) Hierdie opmerking is 'n aanduiding van die unieke van Vollenhoven se eie antropologie - sy herontdekking van die menslike hart - waaroor later meer gesê sal word.

Voorstanders van die pwwt was onder andere Gregorius van Nazianze (329-390 n.C.), terwyl dit in die negentiende eeu deur Lotze en later deur Spencer, Mach, James, Husserl en Whitehead in 'n moderne gees uitgewerk is. (Vgl. Stellingwerff, 1992:237 asook Vollenhoven, 2000 vir die volledige konsepsies van al hierdie denkers.)

\subsection{Gregorius van Nazianze}

Omdat Gregorius van Nazianze (Grieks: Nazianzos en Engels: Gregory of Nazianzus) die eerste Christelike denker is wat volgens Vollenhoven 'n verteenwoordiger van die pwwt was, is dit belangrik om iets meer van hierdie relatief onbekende figuur te wete te kom.

Vir die geskrifte van hierdie vroeg-Christelike Griekse denker kan Schaff en Wace (1955:203-482) geraadpleeg word. Van Unnik (1958:302-303) en Altaner (1960:345-351) bied basiese biografiese en bibliografiese gegewens oor hom. ('n Elektroniese webwerfsoektog sal vir die geïntresseerde talle meer resente boeke en artikels oor hom oplewer.) 
Volgens Vollenhoven val Gregorius binne die periode van die Christelike sintesedenke in 'n tydstorming (nr. 38) wat sterk deur die NeoPlatoniese anti-realisme beïnvloed is (vgl. Vollenhoven, 2000:231). Dit stem ooreen met die insiggewende werk van Reuther (1969, veral p. 130-154) waarna die leser verwys word vir meer detail oor die filosofie onderliggend aan Gregorius se teologiese denke.

Kortliks die volgende: Reuther toon duidelik aan dat en hoe Gregorius (in die lyn met o.a. Origines) 'n versoening tussen die pagane Griekse denke en die Skrif probeer bewerk, sonder om werklik daarin te slaag (vgl. byvoorbeeld Reuther, 1969:154, 155).

Wat sy ontologie betref, dink hy duidelik monisties. Reuther (1969: 149) noem dit wel "dualisme". Dit dui egter nie op Gregorius se ontologie nie, maar op 'n digotomie in sy antroplogie. Volgens Gregorius bestaan die mens uit laere, sigbare stof ('n liggaam) en 'n hoëre, onsigbare, onsterflike deel (gees of siel). In sy siel vertoon die mens verwantskap met God en dra hy God se beeld. Die gees of siel is die eintlike mens. Daarom is die mens se uiteindelike doel om deur middel van katarsis (askese, reiniging, kontemplasie) na die eenheid met God terug te keer (deïfikasie).

In ooreenstemming met hierdie mensvisie word Gregorius se hele lewe gekenmerk deur 'n soms ondraaglike spanning tussen wêreldbetrokkenheid aan die een kant en wêreldvermyding aan die ander kant. Die mens kan God eintlik net op "geestelike" gebied dien, omdat die liggaamlike as sodanig sleg is. Reuther toon byvoorbeeld aan hoe Gregorius asketies probeer leef het asof hy nie 'n liggaam het nie. Sy advies is dat 'n mens in die huwelik (omdat geslagtelike gemeenskap as iets minderwaardig beskou word) moet leef asof jy nie getroud is nie. Aan die openbare (bv. politieke) lewe moet 'n mens deelneem asof jy nie werklik in wêreldse dinge betrokke is nie.

\subsection{Waarom Vollenhoven hom nie met Gregorius se visie kon vereenselwig nie.}

In my (beperkte) bestudering van Gregorius kon ek nie duidelike aanduidings vind dat hy ook 'n pneumatistiese wisselwerkingsteorie (pwwt) huldig nie. Wat wel duidelik geword het, is waarom Vollenhoven - hoewel simpatiek teenoor die pwwt - nie Gregorius se standpunt as sy eie kon aanvaar nie.

Vollenhoven het heel waarskynlik gevoel dat onder al die baie antropologieë, die pwwt die naaste aan die waarheid oor die mens kom. Die pwwt lê klem op die rigtinggewende invloed van die menslike 
gees (pneuma) op die liggaamlike of sigbare lewe, sonder dat die omgekeerde invloed van die chemies-biologiese op die geestelike lewe ontken word (vgl. Vollenhoven, 2005e:104).

Vollenhoven kon egter nie met hierdie mensvisie saamgaan nie, want hy is nie 'n monis nie. Hy dink ook nie digotomisties oor die mens nie en sien nie 'n spanning tussen gees en liggaam soos Gregorius nie. Volgens Vollenhoven ontbreek die hart as sentrum van die mens by die meeste mensvisies, ook by Gregorius. Die hoëre-laere (vertikale) wisselwerking tussen gees en liggaam vervang Vollenhoven in sy eie antropologie dus met die verhouding van binne-buite (innerlik-uiterlik) van die hart en die funksiemantel. Gregorius se poging om 'n sintese tussen die onbybelse Griekse denke en die Woord van God te bewerkstellig, sou Vollenhoven ook afkeur. Dit was onder andere die diepste oorsaak vir Gregorius se wêreldontvlugting en hemelverlange. Volgens Vollenhoven raak 'n mens se religieuse lewe jou hele lewe hier op aarde, dit is 'n konkrete, liggaamlike, alledaagse wandel met en diens aan God. "Longing for heaven" is valse religie (vgl. Vollenhoven, 2005e:105).

Hiermee is voldoende aangedui hoe Vollenhoven probleem-histories die mensvisies deur die eeue geanaliseer het. Vir verdere besonderhede van Vollenhoven oor hierdie tipe konsepsie, vergelyk Bril (1982:124) se trefwoorde "wisselwerkingsteorie" en "pneumatistiese wisselwerkingsteorie" asook Bril (in Vollenhoven, 2000:9 en 414) en Vollenhoven (2005c:440).

Daarmee is die spoorsnywerk egter nie afgehandel nie. Die wyse waarop Vollenhoven die mens in sy eie filosofiese sistematiek beskryf, is die volgende afdeling van hierdie speurtog.

\section{Vollenhoven se sistematiese insigte oor die mens}

In hierdie sistematiese samevatting van Vollenhoven se visie op die mens word hoofsaaklik van gegewens gebruik gemaak uit Vollenhoven (1933; 2000; 2005d en 2005e), Bril (2005), Kok (1996) en Tol en Bril (1992). Agtereenvolgens word gelet op die menslike struktuur en rigting, religie en die beeld van God, asook dood, onsterflikheid, tussentoestand en opstanding.

\subsection{Struktuur en rigting}

Dit is reeds aangetoon dat Vollenhoven elke filosofiese konsepsie op twee maniere tipeer: hoe dit die struktuur van dinge beskou (tipe filosofie of ontologie) en die rigting daarvan (voor, tydens of na die 
sintesedenke, asook die verskillende strominge daarbinne), wat die normatiewe kant daarvan aandui. Antropologies gestel, beantwoord die eerste (tipe) die vraag "Wie is ek?" en die tweede (stroming) die vraag "Wat moet ek doen?" (Die Sein en Sollen gaan sáám.) Daar word agtereenvolgens op Vollenhoven se antwoorde op albei vrae gelet.

\subsection{Die menslike struktuur}

Wat die struktuur van die mens betref, onderskei Vollenhoven al vroeg (1933:31) tussen veertien aspekte, funksies of modaliteite by die mens: die aritmetiese, ruimtelike, fisiese, organiese, emosionele of psigiese, analitiese of logiese, historiese, linguale, sosiale, ekonomiese, estetiese, juridiese, etiese en pistiese of geloof (vgl. ook Vollenhoven, 2005d en 2005e:25, 26 vir 'n vollediger behandeling en vir die historiese aspek ook p. 139 e.v.). Tussen hierdie verskillende modaliteite bestaan ' $n$ noue verband as gevolg van allerlei antisipasies en retrosipasies (vgl. Vollenhoven, 2005d:36-49; 2005e:36-49) waarop nie hier verder ingegaan kan word nie. Wat egter hieruit duidelik word, is dat die mens 'n baie komplekse wese is.

Vollenhoven se modaliteiteleer toon duidelik aan dat die mens 'n totaal verskillende wese as stof, plant en dier is. Stof het net deel aan die eerste drie modaliteite, plante aan die eerste vier, diere aan die eerste vyf, terwyl die mens al veertien aspekte vertoon.

Sy multidimensionele antropologie bied dus 'n veel ryker visie op die mens as baie van die vroeëre en gangbare mensvisies wat slegs 'n een- of twee-dimensionele kyk op die mens het. Hulle definieer die mens byvoorbeeld as 'n fisies-chemiese, rasionele, emosionele of ekonomiese wese en reduseer die ander aspekte tot die een/twee kante van menswees. (By 5.3 hieronder sal een so 'n eensydige mensvisie, die fisikalistiese, ter sprake kom.)

Vollenhoven waarsku in die eerste plek teen 'n funksionalistiese digotomie. Dit beteken dat die hoëre funksies (vanaf die psigiese tot die pistiese) as 'n afsonderlike substansie (d.w.s. as 'n pseudo-ding) beskou word (bv. "siel" genoem), teenoor 'n groepering van die laere modaliteite (die aritmetiese tot die organiese) tot iets afsonderliks (“liggaam" genoem).

In die tweede plek is hy van mening dat, ook al vertoon die mens meer funksies of aspekte as die res van die skepping, die mens nog méér as 'n bloot funksionele wese is (vgl. Bril, 2005:79). Die mens is 
nie net 'n "hoëre" nie, maar ook 'n "dieper" wese as 'n dier. Dit bring ons by die tweede kant van menswees, naamlik die rigtingbepalende.

\subsection{Die menslike rigting}

Hiermee is die hart van Vollenhoven se mensvisie - sy herontdekking van die Bybelse begrip hart - bereik. Antieke (vóórChristelike), Christelike en moderne (ná-Christelike) denkers het soms wel van die modale aspekte van die mens raakgesien, maar nie die hart of kern, die religieuse sentrum van die mens erken nie. (Vgl. 1.4 hierbo, waar aangetoon is dat Vollenhoven (1950:26) die leemte al vroeg by die Grieke ontdek het.)

Hierbo (vgl. 3.5) is reeds genoem (vgl. Bril in Vollenhoven, 2005c: 404) dat, hoewel die rol van die gees (pneuma) in die pwwt meer reg laat geskied aan die werklike stand van sake ten opsigte van die mens, eers die raaksien van die innerlike mens (hart) tot 'n werklike Skrifgetroue antropologie kan lei. Teenoor die antropologie van die pwwt stel Vollenhoven dus die onderskeid van "binne-buite" of "innerlik-uiterlik" voor. Hy sê (vgl. Vollenhoven in Tol \& Bril, 1992: 201) dat by die mens, anders as by die ander geskape dinge, onderskei moet word tussen die modale en die nie-modale of die funksionele en die nie-funksionele hart of siel. Laasgenoemde is die pre-funksionele of "innerlike".

Die plek van die hart is egter nie voor die funksies, of (soos by Dooyeweerd) bo die funksies (bo-tydelik) nie, maar binne die funksiemantel - dus pre-funksioneel (vgl. Vollenhoven, 2000:293). Reeds vroeg al gebruik Vollenhoven (1933:44), met verwysing na 2 Korintiërs 5:1-4 se aardse kleed of tent, die woord funksiemantel en onderskei so tussen die hart en funksiemantel of liggaamlike (vgl. ook Vollenhoven, 2005d:62; 2005e:62).

In Vollenhoven se kort inleiding tot sy sistematiek (Isagoge philosophiae) word hierdie rigtinggewende rol van die hart verder verduidelik. Die mens is nie bloot 'n modale wese nie (vgl. Vollenhoven, 2005d:61-62; 2005e:61-62), want die rigting van sy lewe kan goed of sleg wees, dit wil sê aan God se wet beantwoord of nie (vgl. Kok, 1996:216 e.v.). Daar moet dus iets meer by die mens wees, iets wat "voor" of "agter" die verskillende funksies lê, wat die funksionele lewe (bv. die psigiese, ekonomiese, juridiese) ten goede of ten kwade rig. (Vgl. hier weer Vollenhoven se simpatie met die pneumatiese wwt!) Volgens Vollenhoven is hierdie "iets" die hart. (Hy verwys in hierdie verband na Spr. 4:23; Matt. 12:34b-35; 15:18 en Luk. 
6:45.) In plaas van hart kan siel of gees ook gebruik word. (Vir 'n uitstekende uiteensetting oor die verskillende betekenisse van die begrip hart in die Skrif, ook die religieuse betekenis daarvan, vgl. Von Meyenfeldt, 1950; 1951 en 1964:40 e.v.).

Die verhouding tussen die pre-funksionele hart en die funksionele liggaam of funksiemantel (vgl. Vollenhoven, 2005d:62; 2005e:62 Kok vertaal die begrip in Engels met cloak of functions) is nie dié van 'n hoër groep funksies teenoor 'n laere groep nie. Die hart as innerlike bepaal die koers of rigting van die hele konkrete, liggaamlike lewe. Gehoorsaamheid of ongehoorsaamheid aan God se wet bepaal hierdie geestelike rigting.

\subsection{Religie en beeld van God}

Uit die voorafgaande het die noue verband tussen hart en religie reeds duidelik geword. Von Meyenfeldt (1964:53) dink in dieselfde rigting as hy skryf: "Religion is not one of man's many capacities. No, religion is a matter of the authentic, unadultered man; in other words: religion is a matter of the heart." Vollenhoven (2005d:78; 2005e:78) omskryf religie kernagtig soos volg: "... religion is the relationship of humankind to the God of the covenant in obedience or disobedience to his fundamental law of love" (Vollenhoven verwys hier na Deut. 6:5 en Matt. 22:37).

\subsubsection{Die mens as religieuse wese}

Die mens is dus, anders as die res van die skepping, van nature selfs in sy ongehoorsaamheid aan God se gebooie of die ontkenning van sy bestaan - 'n religieuse wese.

Verder is die mens se religieuse lewe volgens Vollenhoven se antropologie nie beperk tot die hoëre deel van sy bestaan (die siel of gees) nie, maar dit kom na vore in sy hele liggaamlike bestaan, in al sy funksies. Dit bepaal by elke aktiwiteit of dit goed of sleg is - tot eer of tot oneer van God. Dit is in ooreenstemming met wat die Bybel leer: in alles dien 'n mens óf die ware God, óf afgode in sy plek. Von Meyenfeldt (1964:52) sê hieroor:

Religion is not a certain capacity. It is the relationship between God and man in which man is engaged from his innermost parts to his fingertips. It takes hold of man in the deepest and at the same time in the broadest sense possible. 


\subsubsection{Die mens as die beeld van God}

Voorafgaande beïnvloed ook Vollenhoven se verstaan van die Bybelse openbaring dat die mens na die beeld en gelykenis van God geskep is (Gen. 1:26, 27).

In die lang Christelike tradisie tot op hede (vgl. Gregorius van Nazianze hierbo) is geleer dat die siel ontologies aan God verwant is en die mens dus in sy siel die beeld van God dra. Die beeldskap van God is as onverliesbaar beskou. Die mens is dus 'n semigoddelike wese.

Hierteenoor leer Vollenhoven in ooreenstemming met sy duidelike onderskeid tussen God en die skepping, die mens ingesluit, dat dit verkeerd is om van God se beeld in die mens te praat. Dit is meer Skriftuurlik om te sê 'n mens moet die beeld van God wees, of dit vertoon. Dit gebeur nie indien die mens met die goddelike verenig word nie (vgl. Gregorius se strewe na deïfikasie), maar wanneer jy God se grondliggende liefdesgebod gehoorsaam. Saam met sy herontdekking van die menslike hart, het Vollenhoven ook weer die hart van die wet, naamlik die liefde, beklemtoon. Deur lief te hê, vertoon 'n mens die beeld van God en leef jy in die regte rigting waarop God se seën sal rus.

'n Mens is dus die beeld van God, of is dit nie. Die beeldskap is nie onverliesbaar nie. Die beeld van God is volgens die Skrif 'n trek van menswees wat 'n mens as gevolg van ongehoorsaamheid aan God kan mis. As gevolg van die gebrokenheid van die sonde vertoon selfs hulle wat die beeld van God is dit in meerdere of mindere mate (vgl. Vollenhoven in Tol \& Bril, 1992, en Bril in Vollenhoven, 2000: 279 e.v.).

\subsection{Dood, onsterflikheid, tussentoestand en opstanding}

Ook oor hierdie sake - waaroor mense van alle tye vrae stel - het Vollenhoven reeds vroeg (1933) duidelik standpunt ingeneem.

\subsubsection{Dood}

Vollenhoven beskou nie die dood, soos baie Christene in die verlede (vgl. weer Gregorius) as iets begerenswaardigs nie, omdat die siel dan daardeur uit die gevangenis van die liggaam sou verlos word om met God verenig te word nie. Die dood is volgens die Skrif God se straf op die sonde (1 Kor. 15:21, e.a. tekste). Die dood beteken ook 'n verbreking van die bande waarin die mens tot sy omgewing gestaan het (vgl. Job 14:10-14). Die aflegging van die liggaam is 
daarby 'n sekondêre element, wat daaruit blyk dat dit alleen by die eerste dood gebeur. By die tweede dood is die hart of siel reeds met die liggaam herenig (Op. 20:12,13). Let wel: "Liggaam" word hier nie verstaan as die "animale deel" van die mens nie, maar al die menslike funksies wat Paulus (vgl. weer 2 Kor. 5:1-4) met 'n mantel of tentwoning vergelyk.

In ooreenstemming met die Skrif onderskei Vollenhoven (1933:44) dus tweërlei dood. Die eerste dood tref alle mense - die wat nie in God glo nie sowel as gelowiges. Die tweede dood val saam met die ewige straf wat diegene tref wat nie in Christus gered is nie (Op. 20:14 en 21:8 teenoor Op. 2:11 en 20:6; vgl. verder Vollenhoven, 2005d:121, 122, 133, 134, 139; 2005e).

\subsubsection{Onsterflikheid}

Terwyl 'n tweeduisendjarige Christelike tradisie (vgl. weer Gregorius hierbo) tot met Vollenhoven se tyd, en selfs vandag nog, onder die invloed van sommige voor-Christelike Griekse denkers in die onsterflikheid van die siel glo, word dit deur Vollenhoven in die lig van God se Woord bevraagteken.

Onsterflikheid (om nie aan die mag van die dood onderworpe te wees nie) word in die Skrif alleen van God geleer. Die Bybel maak nêrens melding van 'n onsterflike deel (byvoorbeeld die siel) in die geval van die mens nie. Sulke gedagtes is vanuit 'n onbybelse mensvisie in sekere Skrifgedeeltes ingelees. Die mens is ook nie voor die eerste dood onsterflik nie. Onsterflikheid is alleen van toepassing op mense (nie siele nie) wat aan Christus behoort ná hulle opwekking by sy wederkoms.

\subsubsection{Tussentoestand en opstanding}

Oor die sogenaamde tussentoestand sê die Skrif, en dus ook Vollenhoven, baie min. Onder 3.2 hierbo is reeds genoem dat Vollenhoven van mening is dat die ontstaan van die skepping en voortbestaan van die mens na die dood nie wetenskaplik ondersoek kan word nie, maar dat in die geloof aanvaar moet word wat God self daaroor openbaar (vgl. 1 Kor. 2:9).

Die digotomistiese antropologieë by Christene het gewoonlik (onder invloed van o.a. Plato) geleer dat die mens by die dood gedemonteer of uitmekaargehaal word, sodat die liggaam begrawe en die siel na God toe terugkeer. Die Epikureërs in Paulus se tyd (vgl. Hand. $17: 18,32$ ) het egter geglo die mens word by die dood vernietig en 
dit is die einde van sy/haar bestaan. Hierteenoor leer Vollenhoven (vgl. 4.5.1 hierbo) dat die dood nie die vernietiging van die mens inhou nie. Eerder moet gesê word dat die mens by die dood gebreek of losgemaak word van die bande met sy omgewing. Hy stel sy standpunt (vgl. Vollenhoven in Tol \& Bril, 1992:190) soos gewoonlik baie kernagtig: "Ontologisch kunnen wij zeggen dat het bij de dood, bij het graf niet uit is; Christologisch kunnen wij zeggen, dat wij des Heeren zijn."

As gevolg van sy holistiese mensvisie verkies Vollenhoven eerder die Geloofsbelydenis van Nicea bó die Apostoliese Geloofsbelydenis, omdat eersgenoemde die opstanding van die dooies in plaas van (soos laasgenoemde) die opstanding van die liggaam bely (vgl. Bril in Vollenhoven, 2000:293).

Wat die opstanding betref, verwys Vollenhoven na 1 Korintiërs 15:44 wat openbaar dat uit die "natuurlike liggaam" 'n "geestelike liggaam" opgewek sal word. Ook hier is die pneumatiese dus weer belangrik. Vir diegene wat 'n digotomie tussen liggaam en gees aanvaar, klop so 'n Bybelse uitdrukking glad nie. Volgens die Skrif beteken dit egter dat die mens, anders as in die huidige sondige bedeling, volledig deur die Gees van God tot volkome gehoorsaamheid gelei sal word.

Hiermee is die hoofkontoere van Vollenhoven se reformatoriese mensbeskouing geskets. Ons kan hom in die lig daarvan "die filosoof van die hart" noem. Die vraag kan egter gestel word of sy antropologie nog enigsins vir vandag relevant is.

\section{Die betekenis van Vollenhoven se Skrifmatige antropologie vir vandag}

Om die blywende aktualiteit van hierdie Christelike denker se visie op die mens te illustreer word slegs op een resente versamelwerk gekonsentreer: From cells to souls - and beyond: changing portraits of human nature $(2004)^{2}$ onder redaksie van Jeeves. Die kernprobleem daarin is of en hoe moderne wetenskaplike kennis oor die mens versoen kan word met dit wat Christene nog altyd oor die mens geglo het en (volgens hulle) ook deur die Skrif geleer word.

2 Verwysings in afdeling 5 wat slegs met 'n bladsynommer aangedui word, is 'n verwysing na Jeeves (2004). 


\subsection{Die agtergrond}

Navorsing op die gebied van die neurologie, neurobiologie, neuropatologie, neuropsigologie, psigiatrie, genetika en ander vakgebiede het aan die lig gebring dat die menslike brein of sy chemies-fisiesbiologiese faset, sy hele bestaan beïnvloed. Hierdie navorsing het onder andere aangetoon dat biochemiese prosesse 'n groot invloed kan hê op 'n mens se ervaring van wat reg en verkeerd, sonde, skuld en liefde is. Alzheimersiekte (p. 81) lei byvoorbeeld tot 'n radikale verandering in die eie identiteit en kan selfs daartoe lei dat 'n mens groot moeite ondervind om langer te glo of God se teenwoordigheid te ervaar. Ook genetiese defekte kan 'n mens se godsdienstige ervarings beïnvloed (vgl. p. 119). Wetenskaplikes vind dit vandag dus al moeiliker om die vroeëre onderskeid tussen fisieke en geestelike/mentale siektes te handhaaf (p. 124).

Sulke ontdekkings roep veral by Christene ernstige vrae op, soos die volgende: Wanneer begin ' $n$ mens om 'n mens te wees? Wanneer hou 'n mens op om 'n mens of persoon te wees? (vgl. p. 13). Watter rol speel die brein by menswees? Het 'n mens wie se brein ernstig beskadig is ook sy menswees verloor? Is daar iets, en indien wel, wat is dit wat 'n mens anders as 'n dier maak? Beteken dit dat Christene moet afskeid neem van die gedagte dat die mens uit 'n liggaam en ' $n$ siel bestaan? Hierdie suggestie kom dwarsdeur die boek voor (vgl. p. 33, 58, 60, 179). Die mens as liggaamlike wese staan voorop.

\subsection{Die "oplossing"}

Bogenoemde probleme (bv. wanneer die mens mens word of ophou om mens te wees) is valse probleme - die gevolge van 'n digotomistiese mensbeskouing, wat glo dat die mens 'n afsonderlike "deel", naamlik ' $n$ siel nodig het om in vergelyking met diere as mens te kan kwalifiseer. Die skrywers in hierdie bundel verwerp tereg 'n digotomistiese (hulle noem dit 'n "dualistiese") antropologie, maar ongelukkig nie die probleme wat uit dieselfde mensvisie spruit nie.

Al die skrywers is feitlik eenstemmig dat 'n monistiese mensvisie die probleme kan oplos. Die soeke na 'n onsigbare, afsonderlike iets soos 'n "siel" is volgens hulle tot mislukking gedoem (vgl. p. 32, 33). Neurologies is dit immers reeds oortuigend aangetoon dat al die vermoëns wat vroeër aan 'n siel toegeskryf is, eintlik maar die resultate of gevolge van neurofisiologiese prosesse in die brein is (p. 58). 


\subsection{Reduksionistiese fisikalisme}

Bogenoemde standpunt word gewoonlik as fisikalisme (of naturalisme) aangedui. Al wat bestaan, is die fisiese - 'n duidelik monistiese ontologie. Crick (1994:3) reduseer die mens se mentale en geestelike lewe in die volgende woorde tot die fisies-biologiese:

... you, your joys and sorrows, your memories and your ambitions, your sense of identity and free will, are in fact no more than the behavior of a vast assembly of nerve cells and their associated molecules (kursivering bygevoeg om die reduksionisme by Crick te beklemtoon - BJvdW).

\subsection{Nie-reduksionistiese fisikalisme as Christelike antwoord?}

Die Christelike skrywers in die bundel onder redaksie van Jeeves (2004) kan 'n materialistiese/naturalistiese mensbeskouing soos dié van Crick as gevolg van die verreikende implikasie daarvan moeilik aanvaar (p. 63, 173, 180). Dit sou onder andere tot determinisme lei, dit wil sê 'n verwerping van menslike vryheid en verantwoordelikheid. Daar bestaan dan nie meer 'n wesenlike verskil tussen mens en dier nie en die menslike lewe is ook nie meer heilig nie - veral as sy brein nie meer normaal funksioneer nie. Etiese en ander norme word onseker of heeltemal verwerp en geloof in 'n lewe hierna word betwyfel, en nog baie meer.

'n Hele aantal van die skrywers in die Jeeves-bundel vervang dus Crick en andere se reduksionistiese fisikalisme met 'n standpunt wat hulle as "nie-reduksionistiese fisikalisme" aandui (vgl. p. 63 e.v., 184 e.v., 214 e.v.). Hierdie standpunt word soos volg omskryf:

Nonreductive physicalism holds two theses simultaneously: First, it holds that functional properties (thoughts, intentions, fears, etc.) cannot be reduced to physical properties. Second, it holds that causality is nonetheless physical. (p. 214.)

Die vraag is of die twee tesesse nie met mekaar bots nie. 'n Fisikalistiese standpunt kan nie werklik nie-reduksionisties wees nie. Hierdie is egter nie die plek om met die skrywers in Jeeves (2004) in diskussie te tree nie. Die aandag word eerder gevestig op die wyse waarop Vollenhoven kan help om so 'n standpunt te begryp.

\subsection{Beoordeling in die lig van Vollenhoven se mensbeskouing}

Die verskillende skrywers in die bundel van Jeeves sien duidelik 'n monistiese ontologie as die enigste oplossing vir die probleem waarvoor hedendaagse wetenskaplike kennis oor die mens Christene 
stel. Daarom is ook die eenheid van die mens vir hulle belangrik. Wie egter die woord eenheid gebruik, veronderstel daarmee reeds 'n veelheid.

Ook by hierdie denkers is daar dus by die oorspronklike eenheid 'n vertikale divergensie tussen iets hoërs en iets laers. Daar word uitdruklik gestel dat dualiteit sonder dualisme erken word (p. 241, 242) of daar word van "the dual aspect of monism" (p. 244) gepraat. Die hoëre gedeelte van die mens word met verskillende name soos mind, spirit en soulishness aangedui (p. 67).

Op die vraag waar dié hoëre aspek vandaan kom (wat deur Crick ontken word), antwoord hulle dat dit uit die laere ontwikkel (p. 74). Omgekeerd beïnvloed die laere (bv. die chemie van die brein) weer die hoëre en kan die resultate van die moderne, sekulêre wetenskap dus aanvaar word. Parallelistiese antropologieë word dus verwerp ten gunste van 'n soort wisselwerkingsteorie (vgl. p. 240, 243). Op dié wyse is die "siel" gered en kan die mens 'n "embodied soul" of "embodied spirituality" genoem word (vgl. p. 74, 123 en 245). By sommige skrywers word vir hierdie standpunt selfs 'n beroep op die Skrif gemaak (vgl. p. 186, 187). Die Ou en Nuwe Testament sou dan ook 'n monistiese mensvisie verkondig!

\section{6 'n Werklike antwoord}

Vollenhoven kon (hy is reeds in 1978 oorlede) nie kennis neem van hierdie hedendaagse (nie)reduksionisties-fisikalistiese antropologieë nie. Uit hierdie kort weergawe blyk egter dat Vollenhoven sowel simpatiek as krities daarteenoor sou staan.

Positief sou hy die pogings in Jeeves kon waardeer, omdat volgens hom onder al die moontlike mensvisies 'n (pneumatiese) wisselwerkingsteorie die naaste aan die waarheid aangaande die mens gekom het (vgl. 3.5 hierbo).

In die tweede plek is dit egter ook duidelik dat die mensvisies wat Christelike skrywers in Jeeves se boek voorstel nie die volle waarheid oor die mens kan weergee nie. Vollenhoven sou hulle 'n hele end nader daaraan kon bring.

Wat die struktuur van menswees betref, sal Vollenhoven se onderskeid van, behalwe die fisiese, nog dertien ander verskillende modaliteite (vgl. 4.2 hierbo) by die mens tot 'n veel breër visie op die mens kan bydra. Bowendien sal die anti- en retrosipasies wat hy tussen die verskillende funksies van die mens aantoon, kan ver- 
duidelik waarom chemies-biologiese aspekte van die mens 'n invloed kan hê op sy gevoel, denke, etiese handelinge en geloof, terwyl die omgekeerde ook plaasvind. Dit nog afgesien van sy klem op die hart as religieuse sentrum van die mens.

Vollenhoven sou heel waarskynlik soortgelyke vrae aan die skrywers in die boek van Jeeves kon stel as wat Geertsema (2008) aan 'n ander skrywer vra, wat met dieselfde vraagstuk worstel. Om konsekwent te wees moet denkers wat beweer dat menslike denke en wil uit neurofisiologiese prosesse in die brein ontstaan, dit ook op hulle eie visie van toepassing maak.

Belangriker is egter dat Geertsema (al is dit vanuit die filosofie van Dooyeweerd) ook antwoorde probeer bied op hoe dit moontlik is dat te veel wyn 'n mens se denke kan aantas. Sekere chemiese middele kan die mens geestelik beïnvloed, soos byvoorbeeld medikasie vir psigiatriese toestande. Beskadiging van die brein het ook duidelik groter gevolge. Dat dit gebeur, kan nie ontken word nie. Hoe dit moontlik is, is egter 'n probleem.

In ooreenstemming met die modaliteitsleer beskou Geertsema hierdie "interaksie" nie as 'n kousale relasie (van oorsaak en gevolg) nie, maar 'n strukturele verhouding. Dit is moontlik as gevolg van die komplekse, onderlinge vervlegtheid van die verskillende fasette van menswees. Hierdie fasette verskil wel van mekaar, sodat hulle nie reduksionisties tot mekaar herlei mag word nie. Terselfdertyd kan hulle slegs van mekaar onderskei en nooit geskei word nie.

Die menslik brein is dus nie bloot iets fisies-chemies-biologies nie, maar dit is deel van die kompleksiteit van die mens. Anders gestel: dit is 'n menslike brein. Die "eenheid" van menswees vanuit die hart kom tot uitdrukking in al die verskillende fasette. Dit is ek wat dink, kies, glo, ensovoorts en nie my brein nie. Ek ervaar pyn en nie my liggaam nie!

\section{Terugskouende evaluering}

Met enkele slotgedagtes kan hierdie ondersoek afgesluit word.

\subsection{Die weg afgelê}

'n Lang pad is geloop vanaf die vroeg-Christelike denke (Gregorius), na Woltjer (Vollenhoven se leermeester), na die gangbare mensvisies by gereformeerde denkers in Vollenhoven se tyd (Waterink, Hepp), na Vollenhoven se eie reformatoriese standpunt teenoor die voorafgaande, na 'n voorbeeld van kontemporêre Christelike den- 
kers se propagering van 'n monistiese wisselwerkingsteorie (Jeeves, 2004).

\subsection{Die resultaat}

Kritici sou kon opmerk dat Vollenhoven nie werklik 'n bydrae tot die beter verstaan van menswees gelewer het nie. Het hy nie maar bloot die vroeëre, digotomistiese denke ('n hoër-laere-onderskeid) met sy eie - ook digotomistiese skema - van binne-buite, innerlikuiterlik of hart-funksiemantel vervang nie?

Vonk (1963) is byvoorbeeld van mening dat Janse (vgl. Vonk, 1963: 75 e.v.), Vollenhoven (sy idee van 'n funksiemantel, vgl. Vonk, 1963:87, 143) en Telder (vgl. Vonk, 1963:160) wel hard probeer het om 'n digotomistiese mensbeskouing te oorkom. Hulle kon nie werklik daarin slaag nie, veral omdat al drie van hulle glo dat by die dood van die mens tog iets (die siel/hart/gees) bly voortbestaan. Vonk is van mening dat (in digotomistiese taal gestel) die totale mens sterf en weer uit die stof opgewek word. Die dood verdeel die mens dus nie in twee nie. Dood is dood.

Hoe dit ook al sy, Vollenhoven wou nie vanuit so 'n monistiese ontologie na die mens kyk nie. Verder sien hy ook nie digotomisties die hoëre funksies van die mens sáám as 'n afsonderlike komponent teenoor die laere groep modaliteite nie.

Sulke kritiek erken verder ook nie Vollenhoven se belangrike bydrae tot 'n integrale visie op die mens, wat duidelik na vore kom in sy integrale, radikale en totale visie op religie, naamlik dat niks van 'n mens se verhouding tot en diens aan God uitgesluit is nie.

Laastens beklemtoon Vollenhoven ook dat die dood iets abnormaals is en dus as iets sekondêrs beskou moet word. Dit hoort nie tot die oorspronklike skeppingstruktuur van die mens nie, maar is 'n (tydelike) straf van God op die sonde. Daar mag dus nie, terugwerkend van die gebroke toestand by die dood, 'n tweeheid in die mens se bestaan hier en nou ingedra word nie.

Die spoorsny op die voetspore van Vollenhoven, sy voorgangers en diegene na hom, was dus tog die moeite werd. Daaruit het duidelik geblyk dat 'n Skrifgefundeerde, reformatoriese mensbeskouing moontlik is en groot waarde kan hê.

Dit bied as gevolg van die modaliteiteleer 'n ryker mensvisie. Dit bied ook 'n dieper kyk op die mens. Vollenhoven ontdek weer die hart van die mens en liefde as die hart van God se wet. So 'n 
mensbeskouing is ook bevrydend. Dit sny eeue oue dualismes, soos liggaamlik-geestelik, sekulêr-heilig, wêreld en kerk, sosiale betrokkenheid en evangelieverkondiging, wetenskap en geloof by die wortel af, omdat die mens se hele lewe vanuit sy hart religieus bepaal is. Die lewe is religie.

\subsection{Die beperking en waarde van wetenskaplike kennis oor die mens}

Vollenhoven is egter die laaste persoon wat sy eie visie oor die mens as die finale sou beskou. Hy het byvoorbeeld 'n lesing oor die wysgerige antropologie begin (vgl. Vollenhoven, 1963) deur te erken dat, van al die baie raaisels, die raaisel van jou eie menswees seker die moeilikste is. Hy sê verder (Vollenhoven, 2005d:17; 2005e:17) dat enige wetenskap slegs beperkte kennis kan bied. Die werklikheid, veral die mens, is nie begripsmatig ten volle te verstaan nie. 'n Vriend of verloofde is nie 'n begrip nie, maar 'n werklikheid. Die hele werklikheid, die mens ingesluit, bestaan ook sonder die wetenskap daaroor.

Nogtans is 'n poging om die geheim van menswees wetenskaplik te ontrafel nie nutteloos nie. Terwyl Christene soms nog dink dat 'n Christelike filosofie gevaarlik kan wees, of ten minste 'n nuttelose bedryf is, het die waarde daarvan duidelik uit die voorafgaande geblyk. Stellingwerff $(1992: 255,256)$ was dus reg toe hy opgemerk het (vgl. 1.4) dat Vollenhoven 'n filosoof vir alle tye is en aanbeveel het dat hy opnuut deur die jongere geslag ontdek behoort te word.

\subsection{Beskeidenheid}

Die taak van die jongere generasie sal egter nie wees om Vollenhoven te kanoniseer nie, maar om op sy werk voort te bou. Alleen dan kan reg geskied aan die beskeidenheid en verwondering oor die skepping wat so kenmerkend was van hierdie "filosoof van die hart". Dit blyk ten slotte duidelik uit wat hy oor die taak van 'n Christendenker sê:

For a philosopher who believes that God created the cosmos proceeds every time again from the presupposition that the wealth in that which is created will be much greater than has been ascertained up to that time. For such a reason, such a (Christian) philosopher can never say, 'I am ready, look here, a closed system!' On the contrary, her result, though acquired systematically, is always a provisional one, for she remains filled with expectation, attuned to new surprises that ... will 
usually alter earlier findings. (Vollenhoven, 2005d:17; 2005e: 17.)

\section{Geraadpleegde bronne}

ALTANER, B. 1960. Gregory of Nazianzus. (In Graef, H.C., trans. Patrology. Edinburgh: Nelson. p. 345-351.)

BRIL, K.A. 1982. Vollenhoven's laatste werk, 1970-1975. Amsterdam: VUUitgeverij.

BRIL, K.A. 1986. Westerse denkstructuren: een probleemhistorisch onderzoek. Amsterdam: VU-Uitgeverij.

BRIL, K.A. 2005. Vollenhoven's problem-historical method: introduction and explanations. Sioux Center: Dordt College Press.

CRICK, F. 1994. The astonishing hypothesis: the scientific search for the soul. New York: Simon \& Schuster.

DE GRAAFF, A.H., ed. 1977. Views of man and psychology in Christian perspective. Toronto: Institute for Christian Studies. (Mimeograph.)

DE GRAAFF, A.H. 1979. Towards a new anthropological model. (In Kraay, J. \& Tol, A., eds. Hearing and doing: philosophical essays dedicated to H.E. Runner. Toronto: Wedge Publication Foundation. p. 97-118.)

DE VRIES, W.G., red. 1992. Eender en anders: correspondentie tussen K. Schilder en D.H. Th Vollenhoven. Kampen: Kok.

DOOYEWEERD, H. 1942. De leer van de mens in de wijsbegeerte der wetsidee. Correspondentiebladen, 7:134-144.

DOOYEWEERD, H. 1949. Reformatie en scholastiek in de wijsbegeerte. Franeker: Wever.

DOOYEWEERD, H. 1957. A new critique of theoretical thought. Vol. 3. Amsterdam: Paris.

DOOYEWEERD, H. 1960. What is man? (In Dooyeweerd, H. The twilight of Western thought. Nutley: The Craig Press. p. 173-198.)

DOOYEWEERD, H. 1961. De taak ener wijsgerige anthropologie en de doodlopende wegen tot wijsgerige zelfkennis. Philosophia reformata, 26:35-58.

FERNHOUT, H. 1975. Man, faith and religion in Bavinck, Kuyper and Dooyeweerd. Toronto: Institute for Christian Studies. (Thesis for Masters of Philosophy.)

GEERTSEMA, H.G. 2008. Hoe vrij ben jij? Beweging, 72(3):40-45.

JANSE, A. 1934. De mensch als "levende ziel". Amsterdam: Uitgeverij Holland.

JANSE, A. 1938. Van idolen en schepselen. Kampen: Kok.

JANSE, A. 1940. Om "de levende ziel". Goes: Oosterbaan \& Le Cointre.

JEEVES, M., ed. 2004. From cells to souls - and beyond: changing portraits of human nature. Grand Rapids: Eerdmans.

KOK, J. 1992. Vollenhoven: his early development. Sioux Center: Dordt College Press.

KOK, J. 1996. Patterns of the Western mind: a reformed Christian perspective. Potchefstroom: Institute for Reformational Studies.

OUWENEEL, W.J. 1984. Hart en ziel: een Christelijke kijk op de psychologie. Amsterdam: Buijten \& Schipperheijn.

OUWENEEL, W.J. 1986. De leer van de mens: proeve van een Christelijkwijsgerige antropologie. Amsterdam: Buijten \& Schipperheijn. 
REUTHER, R.R. 1969. Gregory of Nazianzus: rhetor and philosopher. Oxford: Clarendon.

SCHAFF, P. \& WACE, H., eds. 1955. S. Gregory of Nazianzen, archbishop of Constantinopel. (In Schaff, P. \& Wace, H. A select library of Nicene and Post-Nicene Fathers of the Christian church. Vol. 7. Grand Rapids: Eerdmans. p. 203-482.)

STELLINGWERFF, J. 1987. De Vrije Universiteit na Kuyper. Kampen: Kok.

STELLINGWERFF, J. 1992. D.H. Th. Vollenhoven (1892-1978): reformator der wijsbegeerte. Baarn: Ten Have.

STELLINGWERFF, J. 2006. Geschiedenis van de reformatorische wijsbegeerte: een Christelijk perspectief. Soest: Stichting voor Reformatorische Wijsbegeerte.

TOL, A. \& BRIL, K.A. 1992. Vollenhoven als wijsgeer: inleidingen en teksten. Amsterdam: Buijten \& Schipperheijn.

VAN DER LAAN, H. 2000. Jan Woltjer (1849-1917): filosoof, classicus, pedagoog. Amsterdam: VU-Uitgeverij.

VAN DER WALT, B.J. 2006. The philosophy of D.H. Th. Vollenhoven (18921978), with special reference to his historiography of philosophy. Tydskrif vir Christelike wetenskap, 42:35-59.

VAN DER WALT, B.J. 2008a. Antheunis Janse van Biggekerke (1890-1960): morning star of a reformational worldview. (In Van der Walt, B.J. The eye is the lamp of the body: worldviews and their impact. Potchefstroom: The Institute for Contemporary Christianity in Africa. p. 189-229.)

VAN DER WALT, B.J. 2008b. The consistent problem-historical method of philosophical historiography. (In Van der Walt, B.J. Anatomy of reformation. Potchefstroom: The Institute for Contemporary Christianity in Africa. p. 531-558.)

VAN UNNIK, W.C. 1958. Gregorius van Nazianzus (329-390). (In Grosheide, F.W. \& Van Itterzon, G.P., reds. Christelijke Encyclopedie. Vol. 3. Kampen: Kok. p. 302-303.)

VOLLENHOVEN, D.H. Th. Verskillende Engelse tekste beskikbaar op internet by onder andere Google en All of life redeemed. www.allofliferedeemed. co.uk/Vollenhoven.htm Datum van gebruik: 11 Sept. 2008.

VOLLENHOVEN, D.H. Th. 1933. Het Calvinisme en de reformatie der wijsbegeerte. Amsterdam: Paris.

VOLLENHOVEN, D.H. Th. 1950. Geschiedenis der wijsbegeerte. Deel 1. Franeker: Wever.

VOLLENHOVEN, D.H. Th. 1963. Wijsgerige anthropologie. (Notas deur B.J. van der Walt van lesing gehou op 28/08/1963 by die Departement Filosofie aan die Potchefstroomse Universiteit vir C.H.O.)

VOLLENHOVEN, D.H. Th. 2000. Schematische kaarten: filosofische concepties in probleemhistorisch verband. Bewerkt door K.A. Bril \& P.J. Boonstra. Amstelveen: De Zaak Haes.

VOLLENHOVEN, D.H. Th. 2005a. Die probleem-historische methode en de geschiedenis der wijsbegeerte. Red. K.A. Bril. Amstelveen: De Zaak Haes.

VOLLENHOVEN, D.H.Th. 2005b. The problem-historical method and the history of philosophy. Ed. by K.A. Bril, translated by J. de Kievit, S. Francke, J.G. Friesen \& R. Sweetman. Amstelveen: De Zaak Haes.

VOLLENHOVEN, D.H. Th. 2005c. Wijsgerig woordenboek. Red. K.A. Bril. Amstelveen: De Zaak Haes. 
VOLLENHOVEN, D.H. Th. 2005d. Isagôgé philosophiae: introduction to philosophy. Ed. by J.H. Kok \& A. Tol. Bilingual edition. Sioux Center: Dordt College Press.

VOLLENHOVEN, D.H. Th. 2005e. Introduction to philosophy. Ed. by J.H. Kok \& A. Tol. Sioux Center: Dordt College Press.

VON MEYENFELDT, F.H. 1950. Het hart (leb, lebab) in het Oude Testament. Leiden: Brill.

VON MEYENFELDT, F.H. 1951. Enige algemene beschouwingen gegrond op de betekenis van het hart in het Oude Testament. (In Zuidema, S.U. \& Popma, K.J., reds. Wetenschappelijke bijdragen door leerlingen van D.H. Th. Vollenhoven aangeboden ter gelegenheid van zijn 25-jarig hoogleraarschap aan de Vrije Universiteit. Franeker: Wever. p. 52-67.)

VON MEYENVELDT, F.H. 1964. The meaning of ethos. Hamilton: The Association for Reformed Scientific Studies.

VONK, C. 1963. De voorzeide leer. Deel 1b: Leviticus. Barendrecht: Drukkerij Barendrecht.

Kernbegrippe:

antropologie

digotomie

filosofie: reformatories

hart/siel

Vollenhoven, D.H. Th.

wisselwerkingsteorie

\title{
Key concepts:
}

\author{
anthropology \\ dichotomy \\ heart/soul \\ interaction, theory of \\ philosophy: reformational \\ Vollenhoven, D.H. Th.
}


